\title{
A Study on the Concept of Third Place in Donald Trump's Speech at Riyadh Summit on May 2017
}

\author{
Correspondence: $\mid \begin{aligned} & \text { Eman Abedelkareem Hijazi } \\ & \text { <emanhijazi258@gmail.com> }>\end{aligned}$ MA in Linguistics and Translation, The Islamic University, Gaza Palestine.
}

\begin{abstract}
The current study investigates the concept of third place in the $45^{\text {th }}$ American President Donald Trump's speech at the Islamic summit held in Riyadh in May 2017. The researcher intends to examine if his speech includes some features of third-place or not. To achieve the study's aims, the researcher investigates the following topics related to Trump's speech in Riyadh if Donald Trump succeeded in using and applying the third place and its approaches to persuade them for pure and seamless reconciliation. The results show some third-place features, such as the full awareness of the historical roots of tensions between the West and Muslim countries. The use of the first-person pronouns (Agency) refers to Trump's declaration on several occasions that Islam is the religion of terrorism, and extremism needed to be faced. Moreover, Trump used techniques to approach the Muslim world throughout the third place, such as logic and avoidance techniques and intertextuality.
\end{abstract}

Keywords: Trump's speech, The Concept of third place, First-person pronoun, Intertextuality

\section{Introduction}

From Saudi Arabia, the birth of Islam, the USA president, Donald Trump, delivered one of the most powerful speeches in May 2017, which is considered as an invitation to open a page of the new American policies. He called for a dozen of the leaders of the Muslim countries to unify all the efforts with the USA to sweep the extremism and terrorism (Iran and ISIS) in the Arab world and ignored the central issue in the middle east Palestinian - Israeli conflict.

Trump presented two critical points; the first one aims at establishing a perfect relationship with the Islamic countries and America. However, the second point is to turn the black page and open a new white one by working together to eliminate Islamic terrorism the battle between evil and good by giving his hands to fight the terrorists wherever they are settling down. Therefore, Trump attempted to justify the negative image of America that some Muslims serve in American military forces, working in the Middle East, specifically in some Muslim countries.

He sometimes justified the American reactions full of contradictions and emphasized the importance of moving forward to build new relations based on mutual respect and shared interests. His speech is divided into three essential topics, starting with a persuasive introduction full of fallacy and fake praise on the hosting in the treasured palace.

On the other hand, the core of his speech connected to the main aspects of the tension between America and the Islamic world, focusing on two cases the Islamic Iranian regime with portraying it as the main enemy for Islam, and the second one that the Islamic terrorism without respecting their being Muslims in some ways.

According to his speech, the conclusion was with an intensive emphasis on the importance of cooperation between America and Muslim countries to drive terrorism out. Although he pretended that he is the best ally in fighting terrorism, to some extent, he used the order words $\{$ I'm not here of lecturing\} to some extent indirectly.

\subsection{Definition and perception of third place}

In the early ninetieth century, the term third-place was coined by the sociologist Ray Oldenburg (1991) early in his book "The Great Good Place". "It's a space where people meet to unwind, discuss and talk about things that matter to them, their neighbourhood and their community, where they can let down their guard, relax, be themselves, develop new friendships and deepen existing ones." (p. 105)

Most of the definitions related to the third-place indicate that locating the self in a metaphorical place between two boundary oppositions is found in our beliefs, such as self and other, here and there, present and past, and local and global (Feng, 2009).

According to Kramsch (1993), the third place allows people to see themselves from the outside and the inside perspectives. Thus, they can know what people of other cultures think about them. On the other hand, (Bhabha, 1990b) argued that people know what is acceptable in their culture and what is not. Knowing the perception of the same behaviour from the perspectives of different cultures will help them avoid ethnocentric views.

Nevertheless, some people believe that the third-place represents a real threat to losing one's identity in which s/he forms a new identity that consists of elements borrowed from different cultures (Kramsch, 2013). Moreover, Bhabha (1994) investigated the idea of having negative and positive sides for the third place in which he thinks that the third place should be seen as an interactive place where two contradictory ideas or behaviours are negotiated until the participants reach a new and unrecognizable way to mediate between these two ideas. This way can be desired or undesired. For example, a Chinese student becomes a more active participant in an intercultural class, asking many questions during the lecture. On the other hand, a Japanese student starts paying less attention to his study and focuses more on enjoying his weekend. This is an undesired result.

The third-place concept plays a determining role in our lives in which it becomes a part of the overall lifestyle and has a beautiful place in negotiation. There is a dire need to recognize that third places have become a non-negotiable asset. The third place is unique working on the development of places since it crosses from generation to generation. 


\subsection{Research questions}

- What are the features of the third-place concept included in the speech?

- How did Trump use the concept of third place to approach the Islamic world?

- How was Trump's choice to use the third-place sufficient to reflect a genuine attempt for reconciliation?

\section{Literature review}

\subsection{General overview}

The need for this study stems from the fact that there aren't lots of previous studies focusing on the third place of his speech, although there are many indications that President Trump used the features of the third place in his speech, and there are only some reports and articles which highlight the linguistic and rhetoric features of his speech. Many reports and articles, such as what was written by Eric Trager in New York daily news in May 2017, focused on applying different techniques for analyzing Trump's speech rhetorically and critically.

While Brandon Friedman for Foreign Policy Research Institute (June 2017) emphasized the analysis of the American policy towards the Middle East countries, especially the Arab country with complete confirmation on opening new white page despite using the same strategies, adding utilizing the wealth of the Arab Gulf countries, Dr Ambreen Agha (2017) analyzed the hidden success achieved by Trump for Israel and how many countries starting dealing with Israel.

Feng (2009) emphasized that the third-place challenges our traditional way of thinking by violating the boundary oppositions that we create and rely on; Kramsch (2013) shed light on the nature of the concept of thirdness) an interdisciplinary.

In a nutshell, during the twentieth century, the concept of third place was introduced, in which the attention has been shifted to focus on ourselves and our dichotomy (Peirce, 1893-1913). Recently it comes to dominant prominence out of the increased need for global and international communication.

\subsection{Historical development of third place}

Barthes (1977) is interested in the semiotic approach in which he revolts against our traditional way of perceiving things throughout introducing a third level of meaning which goes beyond the two boundaries that we know: the informational level, which is associated with the physical environment and the relations between character, and the symbolic level which is associated with the values that we attach to something. He thinks that the meaning is deduced from a third level, which he calls "significance". It remains on the level of the signifier and can trigger an emotional response. Barthes's view agrees with Peirce's (1893-1913) beliefs in which the latter thinks that the meaning of a sign is determined throughout the particular relationship between the viewer and the signifier and borrowing some elements from both: the physical environment (informational level) and the thought of people (symbolic level). Thus, a third-place emerges in which he calls "interpretant". In addition, this activity of interpretant is called "thirdness". If firstness is our comprehension of reality, and secondness is our reaction and interaction within a social context, thirdness is the ability to build meaning out of the two parts and form a sense of identity. In my opinion, the different names given to the third place, such as interpretant and significance, complicate the understanding and studying the concept of third place.

Bakhtin (1981) states that the self has no meaning, but it acquires its meaning throughout a combination with others. To illustrate more, how can we understand a sign produced by a foreign speaker since we should consider that he might act as an individual or a group member? In reality, we should consider both sides to figure out the intended meaning since his/her behaviour will abide by the main principles and rules of his/her group (as cited in Kramsch, 2009). Bhabha (1990a) supports a view in which he inserts that the other is never outside us. It is something that we create when we think that we speak intimately and indigenously between ourselves. In addition, he emphasizes this point again, stating, "(you and we) are mobilized to produce meaning in the passage through a third place" (Bhabha, 1994, p. 303-304). This view is supported by Kramsch (2011) in which she states, "the notion of the third culture must be seen less as a PLACE than as a symbolic PROCESS of meaning-making that sees beyond the dualities of national languages (L1-L2) and national cultures (p. 359).

\section{Methodology}

\subsection{Research design}

Following a principle that has been diagramed in what she was called "Path to cross-cultural understanding" (Kramsch, 1993); the researcher built his method for analyzing Trump's Riyadh speech, applying the following criteria:

- Deep understanding of the self (Trump's own culture).

- Appreciation of the other culture (Muslims" culture) despite attacking the in many situations and occasions.

- Trump's trial to mediate between his own cultures (American and other cultures) (forming a new identity).

\subsection{Procedures}

The researcher downloaded Trump's speech from After downloading all the previous sources, the researcher read the text critically and watched the video in which he looked at the signs that indicate understanding the own culture, appreciating other's culture, mediating between the two cultures.

\section{Data analysis}

Features of third place in Trump's speech, there are:

\subsection{Trump's awareness of the historical and religious roots of tensions between the West and Muslim countries}

The Arab Islamic American summit focused on cooperation and partnership in many areas, mainly combating extremism and terrorism, throwing all the blame on the Islamic Iranian regime and ISIS. According to Nic Robertson, in his report on CNN (May 22, 2017), Trump did not only try to confirm the recognition of Islam as a religion of terrorism indirectly, encountering America's old Arab allies but also, he insisted on the need for giving them the American hands to overcome all the obstacles to be the destination of the flocks.

He added that the fight is between evil and good, emphasizing the role of the religious role of the leader to prevail over the force of terrorism and destabilization. From the beginning, Trump praised the hospitality of the king of KSA in which he intensively and magnificently praised the gracious hosting, the excellent relationship between both the former presidents of America, President Franklin Roosevelt - King AbdulAziz.

"You also hosted me in the treasured home of King Abdul-Aziz, the founder of the Kingdom who united your great people. Working alongside another beloved leader - American President Franklin Roosevelt - King Abdul-Aziz began the 
enduring partnership between our two countries. King Salman: your father would be so proud to see that you are continuing his legacy - and just as he opened the first chapter in our partnership, today we begin a new chapter that will bring lasting benefits to our citizens." (Trump, 2016)

Therefore, President Trump was aware of the historical relationship between both countries starting more than 100 years, focusing too many times on opening a new chapter (approach) of their relation to serving the citizens of countries after king Abdul-Aziz started the first chapter.

He added mainly two unique points; both are historical and unprecedented events, which are very significant for American people who trusted him according to the American election. The first point is the coalition with the Islamic world by describing Islam as the religion of tolerance and faith "one of the world's great faiths and called for tolerance and respect for each other" (Trump, 2016).

The second one is connected with the historic gathering of Muslim leaders to share the Americans in resolving their problem with mutual respect.

Here, the researcher attempts to examine the existence of this feature from a third-place perspective. From one side, Trump knows precisely the natural causes of hatred to Islam in his country after September 11s attacks, in which more than 3000 Americans were killed after attacking the twin trade towers. He tried to appear with the face of victims of these events. From the second side, he knows how the notions of modernity and globalization led some Muslims to view the USA as hostile to Islamic traditions, seeing them as America's hegemony worldwide.

Moreover, he confirmed that some extremists made these attacks that do not represent the actual image of Islam. He stressed that Islam is a religion of peace and dignity, supporting his ideas by talking about his own experience with Muslims and how the king hosted him majestically, and this is why he chose KSA as the first destination after being a president of America. On the other hand, he justified some American actions that led some Muslims to hate America, confirming that the American war against terrorism in Syria was not their choice, and Muslims themselves should fight the terrorists in the same time, he asserted that the American policy towards Syria and Iraq was as a reaction to save the innocent people from terrorism and extremism. Moreover, he focused on two Islamic countries Syria, Iran, and the Hamas party (Gaza strip), as the areas that spring with terrorists, and he admitted that there are lots of innocent killed mistakenly.

Emphasizing that these actions are against the principles of American civilization, ensuring on taking all the required procedures to put an end to these actions by calling for a new beginning based on mutual respect and mutual interests.

Trump outlined the Israelis' sufferings since the beginning, in which he highlights their hopes of having their historical and religious homeland and emphasizing the sacrifices they paid, such as the Holocaust.

Additionally, he referred to the Palestinians' sufferings from siege because Hamas controlled Gaza and Abbas's refusal to come back to the negotiation. Finally, Trump used third place in two major issues. The first one, when he stressed that no one, either Israelis or Palestinians, can deny the rights of the other to live peacefully, confirming that America looks at truth from both sides and their right to live side by side in peace. He focused on his complete support of an intermediate solution: two states for two nations living beside each other peacefully.

The second critical issue related to the Iranian regime, Trump explained how Iran identifies herself in opposition to America and the entire world, shedding light on Iran's engagement in some violent activities against innocent people in Syria and Iraq. Nevertheless, he admits that America has attempted to change the democratically elected government.

\subsection{Talking about the audiences' concerns}

Considering the audiences' concerns are a prominent characteristic of Trump's speeches, The researcher examines this issue in a third-place context. In doing so, he subdivides this point into two categories as follows:

\section{a) Stressing the concept of humanity}

Trump stressed the importance of the shared humanistic values and advised people to adopt them. With giving the most inventing "fake news", Donald Trump said he was not in Saudi Arabia to "lecture" - but then told the world's Islamic preachers what to say, condemned "Islamist terrorism" as if violence was a solely Muslim phenomenon and then announced like an Old Testament he was in "a battle between good and evil". There were no words of compassion, none of the mercy, not a word of apology for his racist, anti-Muslim speeches of last year.

Incredibly, he always blamed the Iranian regime more than Isis itself as the source of massacres and killing people, forgetting what they did in Afghanistan, Iraq and many other Islamic countries.

"Every time a terrorist murders an innocent person and falsely invokes the name of God, it should be an insult to every person of faith, ..." (Trump, 2016)

With a total focus on Islamic terrorism, he glorified Israel and the peace process. He referred to the importance of the peace process and called the Palestinian president to come back to the negotiation according to the assigned agreements between the Palestinian Authority and Israel. In addition, he pointed out the Palestinian's violence, blaming Hamas, the Islamic Palestinian party.

To sum up, he inserted the value of promoting peace, mediating between the two parties in which he advised the Palestinians to stop violence, encouraging the Israelis to practice their rights as an independent country, and motivating the neighbours to start their real and apparent relations with Israel. Moreover, Trump blamed some Muslims who rejected the other's faith and considered his being non-Muslim as a tool to measure one's faith. In other words, if the person believes in the same religion and belongs to the same sector, then he is religious like us On the other hand, he emphasized how some western countries impede Muslim citizens from practising their religion covertly.

To sum up, Trump put himself in a middle position in which he refused all violence that prevented anyone from practising his own religious beliefs, emphasizing that religion should bring people with each other despite his being anti -Muslims. Calling for a dialogue between religions, Trump used the third place to conceive a dozen leaders who had good wildlings towards Islam.

\section{b) Trump's Carefulness whenever he touches sensitive Islamic issues}

Trump tackled the issue of women equality that he issued an order allowing women to benefit from government services such as education and healthcare without getting the consent of a guardian by focusing on Islam (the religion of tolerance).

"The way you address those human rights issues and women's rights issues is to improve the conditions in the region."

(Trump, 2016) 
At the same time, he implicitly criticized some Muslim countries (focusing on KSA) that do not allow women to work in leading positions or even drive a car. He asked them to revise these points for more improvement.

"There are efforts underway to, I think, improve the rights of women, the participation of women in society throughout the region." (Trump, 2016)

Finally, he used the third-place concept when referring to his respect for all women who choose to live according to their choice, not according to their family's choice.

At the same time in the USA, he attacked some famous migrants' women, with emphasis on the issues of women who can contribute to developing the country as boys do, encouraging employing them in leading positions, and expressing America willingness to play a role in supporting Muslim women in terms of education and establishing a micro-financial business.

\section{c) Careful use of pronouns}

Trump's victory speeches are characterized by the extensive use of the Pronoun "we", "you" (order words) compared with "I" as in "I'm not here for lecturing".

Trump uses "we" excessively to shorten the distance between America (represented by Trump) and Islam (represented by his audience Islamic country), to mediate between the two cultures, and to minimize the differences in their views, although sometimes he uses the order speech such as "drive them out".

By deploying first singular (I'm, We) and second-person pronouns (You), Trump attempted to bridge the gaps between the two cultures by unifying America and Islam against the ferocious extremists and terrorists who do not differentiate between Killing a Muslim and anyone from other nations, such as what happened with the twins of the trade towers. He concentrated on this idea when he sent the greetings of Islam from the Muslim communities in America to Egyptians and Muslims in other countries with intensive thanking all countries who work with them.

\subsection{The ways that Trump applied to approach the Muslim world throughout the third place}

\section{a) Using a logical technique}

It is a sub-category of a larger unit, called enforcement technique, in which it aims at proving the speaker's sincerity; proposes it. Zheng (2000). The researcher attempts to examine the usage of this technique in a third-place context. Trump supported his position in third place with some evidence that appeals to the mind and the heart of his addressee, inviting him to think logically. For example, when he advised the Palestinians to put off violence as he called, returning to the negotiation process and accepting the two countries' solution.

Moreover, he used this technique to prove his point that America is never at war with Islam., but the fundamental conflict between Muslims themselves, such as ISIS, the Iranian regime, Shetti and Sunni. In addition, he explained the contribution of Muslim people in developing America in which they build their business, serve in the military forces and work at American universities and other official institutions. Therefore, it is clear that Trump invited his audience to think logically and differentiate between their friends and their enemies, and they are in the same trench, suffering from terrorism.

\section{b) Using avoidance technique}

This technique avoids dealing with or even talking about any harmful deeds (Zheng, 2000). The researcher attempts to examine if Trump uses avoidance to hide his real intention towards the Islamic World through his usage of the third-place in context. Despite his thanking and praising Islam as a religion of tolerance.

Trump avoided diving deeper into some details related to Islamic norms and values, highlighting the tension between the West and Islam because they do not coincide with his call for putting the sad past aside and moving forward to start a new beginning (New chapter and new approach). For example, Trump tackled democracy, stating that there has been much controversy regarding promoting democracy and avoiding illustrating its negative side. His main speech concerned with clarifying what is meant by democracy and its importance only for Muslims Arab countries with apparent avoidance that the American presidency attempts to change the democratically elected regime in Iran, and insisted on his unhidden willingness to start fighting with them as if Iran and Syria are the significant issues, causing the conflict in the Middle East.

\section{c) Intertextuality}

Intertextuality is considered an essential communicative strategy for persuasion since the speaker illustrates his ideas throughout other's valuable perspectives (Waaijman, 2010). Intertextuality is the Latin word "intertexto," meaning to intermingle while weaving. Thus, it can be defined as a term first introduced by French semiotician Julia Kristeva in the late sixty years of the twentieth century. Therefore, borrowing some elements or ideas from previous texts is defined as creating new text with similar meaning.

In this paper, the researcher tries to apply this technique in a third-place context. Trump mentioned diverse valuable resources to support his ideas, starting from praising the magnificent hospitality, talking about combating Islamic extremism, and emphasizing human rights in the Middle East, mainly women's rights. He used some words from the Old Testament, Atawrah (evil and sound) and praised Islam as the faith religion.

According to his perspective, Trump shaded the lights on the true principles of Islam, rejecting the idea of killing innocents.

"Whoever saves an innocent as if he saves all the mankind, and whoever kills an innocent as if he kills all the mankind."

(Trump, 2016)

\section{Result and Conclusion}

The concept of the third place was utilized powerfully since the American president, Donald Trump, called for a new white page between America and Muslim countries since that white page eliminates their differences and brings them together to face challenges and share progress in many areas such as economic and defense affairs to encounter the dangers of the Iranian regime and Hezbollah.

Moreover, Trump succeeded in imploring the leaders of Muslim countries to take the USA's hands to protect the innocent people in Syria and other Arab regions and support KSA in her war against the terrorists in Yemen. Adding the economic success achieved by Trump, he came back to his nation with more than four hundred dollars to generate millions of new jobs for the unemployed and earned the most significant victory in which he succeeded successfully taking one of the most critical countries in the Middle East to his side (KSA). 
Therefore, this study reveals how Trump utilized third place in his speech full of fallacies to approach the Muslim world and intermediate between cultures to achieve economic and political affairs.

To sum up, the study found many features of the third place, the awareness of the religious and historical roots of tensions between the West and Muslim countries, talking about the audiences' concerns, and careful use of pronouns. Also, Trump used different methods for implementing the third place, such as intertextuality and using logic and avoidance techniques.

\section{References}

Agha, A. (June, 2017). US President Donald Trump's visit to Riyadh and Jerusalem Reasserting Realpolitik. Indian council of world affairs.

Barthes, R. (1977). The Third Meaning: Image-Music-Text. New York: The Noonday Press.

Bhabha, H. (1990a). Nation and Narration. London: Routledge.

Bhabha, H. (1990b). The Third Place. In J. Rutherford (ed). Identity, Community, Culture, Difference (207-221). London: Lawrence and Wishart.

Bhabha, H. (1994). The Location of Culture. London and New York: Routledge.

Calfas, J. (May 21, 2017). http://time.com/4787609/donald-trump-saudi-arabia-speech

Feng, A. (2009). Becoming Interculturally Competent in a Third Place. In D. Landis, M. Bennett, and J. Bennett (eds). Handbook of Intercultural Training. London: international educational and professional publisher.

Fisk, R. (May 21, 2017). Donald Trump's speech to the Muslim world was filled with hypocrisy and condescension, https://www.independent.co.uk/voices/donald-trump-saudi-arabia-muslim-speech-a7747856.html

Keyword, M. (2004). Telecollaborative model for lingua culture learning $\{$ PhD. Thesis $\}$. Ireland: Dublin university.

Kramsch, K. (1993). Context and Culture in Language Reaching. Oxford: oxford university press.

Kramsch, K. (2009). The third Culture and language education. In V. Cook and L. Wei (eds), The Handbook of Applied Linguistics (253-261). London. Continuum.

Kramsch, K. (2011). The symbolic dimensions of the intercultural. Language teaching journal, 44(3), 354-376.

Kramsch, K. (2013). Culture in Foreign Language Teaching. Iranian Journal of Language Teaching Research, 1(1), 57-78.

Kearney, E. (2015). Intercultural Learning in Modern Language Education Expanding Meaning-Making Potentials. UK: Nicholas House.

Peirce, S. (1989-1955). Philosophical Writings of Peirce. Translated by J. Buchler. New York: Dover Publication.

Trager, E. (May, 2017). The speech of Trump at the Islamic summit. New York daily news.

Waaijman, K. (2010). Intertextuality: On the Use of the Bible in Mystical Texts. Hervomade Teologiese Studies, 66, 1-7.

Zheng, T. (2000). Characteristics of Australian Political Language rhetoric: Tactics of gaining public support and shirking responsibility. Journal of intercultural communication, 4, 1-3.

E-Sources: (Trump, 2016)... )

https://www.youtube.com/watch?v=jZSyLedsc8k

http://www.bbc.com/news/world-us-canada-39989548 